\title{
A Contrastive Study of the Stative Feature in English $^{*}$
}

\author{
Yi Wang \\ School of Foreign Languages, Chongqing University of Posts and Telecommunications, Nan'an, Chongqing, China
}

\begin{abstract}
Compared with Chinese, English language is characterized by the features of, namely, hypotactic, impersonal, passive, stative, abstract, substitutive, and so forth. These traits are interrelated and interact on each other. By means of contrastive analysis, the current paper represents an attempt to discuss the preponderance of stative expressions in English, their philosophical background, representations in various forms and implications in English writing and translation.
\end{abstract}

Index Terms - stative feature in English, nominalization, preponderance of prepositions, verbs of feeble phenomenality, contrastive study

\section{INTRODUCTION}

Studies on English language have been an incessant process among scholars both home and abroad. Compared with Chinese, English language has many characteristics, namely, hypotactic, impersonal, passive, stative, abstract, substitutive, and so forth. As a matter of fact, these traits of English language are interrelated and interact on each other. For instance, one of the impersonal features prefers noun subject to person subject, which reduces the use frequency of persons or actions. As a result, English sentences are usually peppered with matter subjects and prepositional phrases which make them seem stative and objective. Therefore, the impersonal features, to some extent, facilitate the stative features of English which in turn exert influence upon the former.

In spite of the various traits of English, anyway, the characteristic of stative expressions in English never ceases to amaze me. The paper intends to investigate the stative characteristic of English language. By means of contrastive analysis, this current paper is an attempt to discuss the preponderance of stative expressions in English, their philosophical background, representations in various forms and implications in English writing and translation.

Let us take a first glance at the following examples in order to have a general impression of what stative expression indicates:

That scholar is of the opinion that the provision of English curriculum to primary school pupils is not feasible in China.

那位学者认为在中国, 小学开设英语课是不合适的。

With these words she went away.

说完这些话, 她便走开了。

She had surfaced with less visibility in the policy decision.

在决策过程中，她已经不那么抛头露面了。

We must not lose sight of the fact that environmental pollution is getting worse and worse in our country.

我们不能忽视这一事实，环境污染在我国日益严重。

The students are intensely cautious not to make mistakes in spelling.

学生们非常小心, 免得出现拼写错误。

A glance at the underlined parts will enlighten us on the different part of speech used between English and Chinese. Obviously, English language usually takes the stative forms so that they are replaced with dynamic expressions in Chinese when we are doing translation.

The method of analysis employed in my paper is contrastive approach. Contrastive approach is one of the methods of language study, which has become prosperous since the fifties of the $20^{\text {th }}$ century. Through contrast between two different languages, their differences will be discovered and taken into consideration in the course of communication. It is cited from Ellis (1985) that Lado (1957), one of the prime movers of contrastive analysis, makes clear, "The teacher who has made comparison of the foreign language with the native language of the students will know what the real problems are and can provide for teaching them". The late scholar, Lv Shuxiang, in his book Studying Grammar by Contrast, lays great emphasis on the significance and generalization of the method of contrast.

\footnotetext{
* Fund: 2014 Chongqing Planning Project of Philosophy and Social Sciences (2014SKZ20): The Cognitive Construction Grammar Approach to the English Non-finite Complement Clauses; Chongqing Social Science Planning and Cultivation Project (2015PY07): The Cognitive Semantic Study of to Infinitive and -ing Constructions
} 


\section{Definitions: The CONCEPT OF "STATIVE"}

Compared with Chinese, being stative is typical of English language. The concept of "Stative" can be best explained by the distinction of stative and dynamic, which was elaborated by Quirk (1972:48), as in his book A Grammar of Contemporary English:

Broadly speaking, nouns can be characterized naturally as "stative" in that they refer to entities that are regarded as stable, whether these are concrete (physical) like house, table, paper, or abstract (of the mind) like hope, botany, length. At the opposite pole, verbs can be equally naturally characterized as "dynamic": they are fitted (by their capacity to show tense and aspect, for example) to indicate action, activity and temporary or changing conditions.

These relations between the open classes can be summarized thus:

$\begin{array}{ll}\text { STATIVE } & \text { noun } \leftrightarrow \text { adjective } \\ \text { DYNAMIC } & \text { verb adverb }\end{array}$

In Quirk's description, noun and adjective are defined as stative while verb and adverb as dynamic. These are only definitions contemplated lexically or in other words grammatically. The concept of stative and dynamic can also be understood from the syntactical level. The stative being is not confined to employment of the noun and adjective, but noun phrases, prepositional phrases, phrases of feeble phenomenality, etc. These definitions of being stative are the basis of what is adopted in this paper.

Another point which merits mentioning is that the concept of stative is a relative perception. Stative and dynamic are usually combined to reflect the characteristic of English language. In this paper, what is defined as stative is usually compared with the dynamic feature of Chinese. The characteristic of English language can be fully understood by comparing it to another language.

In the course of English-Chinese translation, stative and dynamic are two relative concepts. It is rash and irrational to run to extremes to claim absolute stativeness of English and dynamic feature of Chinese.

Let's take a look at some stative expressions which are usually employed to convey dynamic scenes in Chinese.

He is a good eater and a good sleeper.

他能吃能睡。

Ford's first pledge was, "Mr. President, you have my support and my loyalty."

福特一开始就保证说: “总统先生, 我支持您, 并效忠于您。”

Harvard, despite its own estimate of itself, was ultimately an academic haven where an error of interpretation could result only in loss of face, not in extinction.

哈佛大学, 不管它如何自命高明, 终究还是个学府胜地, 在那里把问题看错了, 无非丢脸而已, 总不至于完 蛋。

On foot, on horseback, in litters, in carriages, they fled for their lives.

他们或徒步, 或骑马, 或坐轿子, 或乘马车, 纷纷逃命。

From the above examples, it is obvious that English language is characteristic of stative expressions. However, when it comes to English-Chinese translation, the usual method is to change stative expressions of English into dynamic equivalents in Chinese.

\section{PhilosophicAl BACKGROUND}

Compared with the subjective way of thinking, one notable philosophical difference is the objective consciousness of westerners. Western people tend to think objectively. This can be traced back to the Aristotelian philosophy which advocates formal logics, and the philosophy of rationalism which permeates Europe from sixteenth to eighteenth century. The advocate of rationalism inevitably upholds the clear differentiation between subject and object. The object in the western culture is given greater attention than that in the Chinese culture, in which subject consciousness is emphasized and the focus of attention is usually prioritized to human being.

The reason why stative expressions are well preferred can be attributed to many factors. Firstly, stative expressions are more formal and precise. They are usually employed in formal documents, like business contract, law proceedings, academic papers, and official letters and so on and so forth. Leech (1974:25) points out that formal written language often goes with an impersonal style, i.e. one in which the speaker does not refer directly to himself or his readers, but avoids the pronouns $I$, you, we. Some of the common features of impersonal language are passives, sentence beginning with introductory it, and abstract nouns. Secondly, as Jespersen (1951) holds the opinion that the more advanced a language is, the more developed is its power of expressing abstract or general ideas. This subsequently requires abstract nouns, objective noun phrases instead of subjective ones. All of these are the demonstration of stative expressions. Thirdly, it is closely related to thinking patterns of westerners. Western thinking pattern tends to lay more emphasis on analysis in terms of logic whereas Chinese thinking pattern is more likely to be a synthesis in terms of images. Analysis requires logic, objectiveness and conceptualization; synthesis requires image, subjectivity and concreteness. Logic, objectiveness and conceptualization facilitate the stative feature of English language. In the following parts, representations of stativeness in English will be illustrated and its implications will be further discussed.

Anyway, there are plenty of factors contributing to the stative feature of English language. Some people even prefer to use stative expressions just to show their superior social status. 


\section{REPRESENTATIONS OF STATIVE EXPRESSIONS IN ENGLISH}

How does the English language encode stativeness through linguistic forms? The following is some of the representations of stative expressions in English. The linguistic devices include: nominalization, preponderance of prepositions, verbs of feeble phenomenality, stative adjective or adverb, etc.

Nominalization: the common phenomenon of English language

A nominalization is a noun phrase that has a systematic correspondence with a clausal predication which includes a head noun morphologically related to a corresponding verb (Quirk 1985:1289). For example, abstract nouns can be employed to express motion, behavior, change, state, quality, emotion, etc. in his book the Philosophy of Grammar, Jespersen says, "It seems possible to express ideas with greater precision and adequacy by means of nouns than by means of the more pictorial verbs."

In Changing English, Potter (1969:101) points out that the English language has the tendency of "preponderance of nouns over verbs". This preponderance is apt for concise expression, flexible sentence-making and smooth writing style. It also facilitates the communication of complicated ideas. He gives vivid examples to illustrate his point. For example, the sentence of "London's growth is rapid" is preferred to "London is growing rapidly." And in another example, "John's arrival was premature" is preferred to "John came too soon." The reason why stative expressions are favored in the above two examples is that they are more literary and bear more connotations. Please take a look at following instances:

Freedom-loving people everywhere condemned them because they violated the agreement reached at Helsinki and abused basic human rights in their own country.

The abuse of basic human rights in their own country in violation of the agreement reached at Helsinki earned them the condemnation of freedom-loving people everywhere.

他们违反在赫尔辛基达成的协议，在国内侵犯基本人权，因此受到了各地热爱自由的人们的谴责。

Nominal style of writing can make narration precise and appropriate. But it merits mentioning that overuse of nominal style can make it difficult for readers to perceive the meaning. Therefore, there is a certain degree in which stative expressions are employed.

\section{Preponderance of prepositions}

The preponderance of nouns is bound to generate the prevalence of prepositions in that they are usually put before nouns or nouns phrases to make sentences. The tendency of stative state seems all the more prominent with the preponderance of nouns and prepositions combined. Many prepositions in English are used not only to achieve the effect when they are functioning as prepositions equaling to what they are in Chinese but also to express some ideas of which in Chinese only verbs can present. Therefore, some prepositions or prepositional phrases with a meaning of action will be transformed into dynamic or others when translated into Chinese.

With these words she went away.

说完这些话, 她便走开了。

We here highly resolve that this nation, under god, shall have a new birth of freedom; and that government of the people, by the people, for the people, shall not perish from the earth.

我们要在这里下定最大的决心，我们要使国家在上帝福佑下得到自由的新生，要使这个民有、民治、民享的 政府永世长存。

They immediately set out in pursuit of the enemy.

他们立刻出发去追击敌人。

The University of New Hampshire has a strict policy against hiring faculty wives.

新罕布什尔大学有一条严格的规定, 禁止雇佣教职员工的妻子。

Are you for or against the plan?

你支持还是反对这项计划?

Opening on each side from the river were gardens, courts, and cloisters; long successions of white pillars among wreaths of vine. 排。

呈现在河岸两边的是花园、庭院以及修道院; 是缭绕的葡萄藤花掩映的白色的石柱, 一根接一根, 长长的一

\section{Verbs of feeble phenomenality}

There are plenty of stative expressions in English taking the form of feeble verbs, such as the most frequently used verb be and do, have, become, get, grow, feel, go and so on. They are verbs of feeble phenomenality. Although these verbs bear a meaning of action, they are less dynamic and colorful. For example:

There was a tropical storm off the east coast of Florida.

佛罗里达东海岸有一场热带风暴。

A tropical storm lashed the east coast of Florida.

一场热带风暴袭击了佛罗里达东海岸。

It is noticeable that the sentence using the sentence pattern of "there is" is more stative than that using concrete verb. The translation of the first sentence is also stative and less vivid and dynamic than the second translation. Therefore, 
stative expressions in this case are often transformed into verbs when translated into Chinese.

It can be often observed that the preponderance of "noun+preposition" is represented in the phrases of feeble phenomenality which dilute or debilitate the original meaning. Thus the stative state is being enhanced. For example:

For centuries, the novel captured great admiration from the broad readers from one generation after another, and scholars making researches on A Dream of Red Mansions emerged in swarms and the "Redology", the study on the novel, soon became a branch of special learning.

几百年来, 世世代代许多读者为之倾倒。《红楼梦》的研究者蜂起, 渐渐地“红学”发展成了一门专门的学问。

As we all know that $\mathrm{V}+\mathrm{N}+$ (prep) sentence pattern expresses the conception of action. The conceptualized $\mathrm{N}$ denotes the abstract noun of action. And the action of $\mathrm{V}$ has been diluted or debilitated. For instance, have a look at..., take care of..., pay attention to.... The verbs "have, take and pay" in the foregoing example have been debilitated. That is why some linguists call them verbs of feeble phenomenality. It is one of the representations of stative tendency in English language. These verbs can also be substituted for verbs of special meaning. In that case, not only is the effect of verb itself reinforced, but also a special rhetoric function can be achieved. Let us take have a look at and its Chinese translations for example, the verb have can be substituted as:

get a look at... 有机会看... 一眼

throw a look at... 漫不经心地朝...看一眼

grab a look at... 抢着看...一眼

steal a look at... 偷偷地看... 一眼

sneak a look at...鬼鬼崇崇地看 ... 一眼

be given a look at... 被允许看... 一眼

Stative adjective or adverb

Stative expressions of adjective derivatives of verbs in English can often present meanings of actions. These adjectives usually function as predicates in sentences. For example:

I am a bit worried that something might go wrong.

我有点担心要出什么事。

I am doubtful whether he is still alive.

我怀疑他是否还活着。

The fact that she was able to send a message was a hint. But I had to be cautious.

她能够给我带个信儿这件事就是个暗示。但是我必须小心谨慎。

The doctor felt sympathetic with his patients.

医生同情他的病人。

Adverbs can also be used to express meaning of verbs:

I am afraid Mr. Brown is out, but he will be in soon.

恐怕布朗先生出去了, 但是他很快就会回来的。

Down with the old and up with the new.

破旧立新。

Well, critics may ask whether it is always with the case that stative expressions in English are preferred. I incline to the opinion that it is far more difficult to give a yes or no answer. There should be a balance between them. If you find the majority of your passage is using stative expressions, some dynamic ones will capture readers' eyes and will make a total difference from the common writing. Therefore, it is held that although there is a tendency that English language has a characteristic of being stative, it does not absolutely follow that you should overreact and flood your English writing with all the stative expressions. There is always a desired equilibrium to be achieved.

\section{IMPLICATIONS IN ENGLISH WRITING}

When writing in English, we are often influenced by our mother tongue. Consequently, it appears to be natural that Chinese students are often corrected with their so called English with Chinese characteristics (Chinglish). Thought and language are closely related. Language is the material form of thought. The contents and patterns of thought influence and to some degree determine the ways of expression. The "Sapir-Whorf hypothesis", as it came to be called, combines two principles. The first is known as linguistic determinism: it states that language determines the way we think. The second follows from this, and is known as linguistic relativity: it states that the distinctions encoded in one language are not found in any other language (http://courses.wcsu.edu/valkommen/thought.html) and that the differences in language reflect the different views of different people.

Therefore, people from different cultures and with different mother tongues think and behave differently. There is a great diversity among their ways of thinking. Well, at the same time, this different way of thinking influences second language acquisition. Here comes a phenomenon called language transfer, which linguistically means what the learners carry over to or generalize in their knowledge about their native language (NL) to help them learn to use a target language (TL). In this manner, when communicating in TL, learners usually express themselves by the aid of phonetic, lexical, and structural rules of NL and by the aid of culture and customs rooted in NL. When learning from NL assists 
learning in TL, this is referred to as positive transfer; when learning from NL interferes with learning in TL, this is referred to as negative transfer. Therefore, we should try our best to avoid negative transfer when learning a TL.

Let us say in English “直到早晨五点钟我才睡着”, most of us might rashly come to the English version as: I did not sleep until five o'clock in the morning. On second thoughts, however, the above English version is wrongly constructed. "Sleep" in the above sentence can be defined as stative state, while the original meaning is to express dynamic meaning. Here a dynamic verb form should be used instead of the stative one. So the correct one should be as follows, I did not fall asleep until five o'clock in the morning.

Therefore, when it comes to English writing, a language learner should bear in mind from time to time the differences between native language and English language, especially the stative feature of English and the dynamic one of Chinese. In the process of English writing, an accurate application of the stative expressions facilitates considerably in processing effective sentences. The following part will elaborate upon its application to translation between Chinese and English.

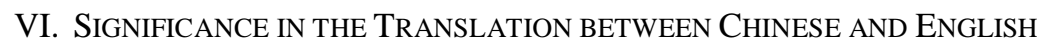

Verbal predicate in English sentence is strictly restrained because of its morphological changes of verbs. There is only one finite verb in one sentence, which necessitates that when it comes to express the concept of action, other means rather other relying on the finite verbs, such as nonfinite verbs, prepositions, adverbs, adjectives, etc. are employed to do so. Consequently, nouns and prepositions are the most effective words to express the state of action.

In Chinese, however, verbs have no morphological changes. Verbs in Chinese have more freedom and greater power to form sentences. So in the English-Chinese translation or vice versa, transformation between stative and dynamic expressions becomes the rule of thumb. Take a look at following examples:

Back and forth his head swiveled, desire waxing, resolution waning.

他来回晃着脑袋, 欲望在膨胀, 意志在萎缩。

An acquaintance with the modern Chinese history is helpful to the study of Chinese revolution.

了解一下中国的近代史, 对研究中国革命是有帮助的。

一个人能力有大小, 但只要有这点精神, 他就是一个高尚的人, 一个纯粹的人, 一个脱离了低级趣味的人, 一个有益于人民的人。

A man's ability may be great or small, but if he has this spirit, he is already noble-minded and pure, a man of moral integrity and above vulgar interests, a man who is of value to the people.

一切爱好和平的人名都要求全面禁止核武器, 彻底销毁核武器。

All peace-loving people demand the complete prohibition and thorough destruction of nuclear weapons.

她深信, 只有对历史加以透彻研究, 才能真正学到知识。

She is in the full conviction that real knowledge is the end product of a thorough study of the history.

Aggression took many forms: the unilateral denunciation of treaties and international commitments, interference in the internal affairs of other states, the use of threats against weaker neighbors, the imposition of unequal relationships, outright armed attack against the territories of other states and their dismemberment, the subjugation of colonial peoples and the denial of the right of self-determination and fundamental human rights.

侵略有许多形式: 单方面废除条约与国际义务, 王涉别国内政, 对较弱邻国实施威胁, 强迫实行不平等关系, 赤裸裸武装进攻别国领土和肢解别国，征服殖民地民族，否认自决权和基本人权。

That would be the confirmation that it was in general use.

这将证实其用途士分普遍。

The very first sight of her made him fall in love with her.

他对她二见钟情。

In the last two instances, the paronyms (confirmation, sight) express the verbal action instead of using the verbs (confirm, see).

English language contains many forms of stative expressions, but not all of them will be altered into dynamic ones when the translation of Chinese is concerned. Every different form has its own characteristics and it is damned too hard to find a generally uniform solution to every case. However, a general rule could be drawn, that is, only if there is a meaning of action hidden in or behind the stative expression, no matter which form it takes, there may be the possibility of transforming it into dynamic expression in the course of English-Chinese translation.

\section{CONCLUSION}

The study of "dynamic and stative" has long been discussed among linguists. Quirk, in his book A Grammar of Contemporary English, defines the concept of dynamic and stative. Potter points out in his book Changing English the idea of "preponderance of nouns over verbs". Potter analyzes the loss of distinction between adjective and noun when a noun functions as a modifier. Through comparison and contrast, a better understanding of English will be obtained. And the stative feature will undoubtedly contribute to effective English writing and idiomatic way of translation. For those Chinese learners of English, these representations should be borne in mind when it comes to communication in English. 
Only being acquainted with these features is far from adequate. Reading, writing and translation practices are needed from time to time to incorporate these features into practice.

\section{REFERENCES}

[1] Ellis, R. (1985). Understanding second language acquisition. Oxford: Oxford University Press.

[2] http://courses.wcsu.edu/valkommen/thought.html.

[3] Jespersen, Otto. (1951). The philosophy of grammar. London: Routledge.

[4] Lado, R. (1957). Linguistics across cultures: Applied linguistics for language teachers. Ann Arbor. Michigan: University of Michigan.

[5] Leech, G. \& J. Svartvik. (1974). A communicative grammar of English. London: Longman Group Ltd.

[6] Lian Shuneng. (1993). Contrastive studies of English and Chinese. Beijing: Higher Education Press.

[7] Lu Gusun. (1993). The English-Chinese dictionary. Shanghai: Shanghai Translation Publishing House.

[8] Lv Shuxiang. (1977). Studying grammar by contrast. Language Teaching and Research vol.2, edited by Beijing Language and Culture University.

[9] Pan Wenguo. (2004). An outline of Chinese-English contrastive studies. Beijing: Beijing Language and Culture University Press.

[10] Potter, S. (1969). Changing English. London: Andre Deutsch.

[11] Quirk, R., S. Greenbaum, G. Leech, \& J. Svartvik. (1972). A grammar of contemporary English. Essex: Longman Group Limited.

[12] Quirk, R., S. Greenbaum, G. Leech, \& J. Svartvik. (1985). A comprehensive grammar of the English Language. London and New York: Longman Group Ltd.

[13] Saeed, J. I. (2000). Semantics. Beijing: Foreign Language Teaching and Research Press.

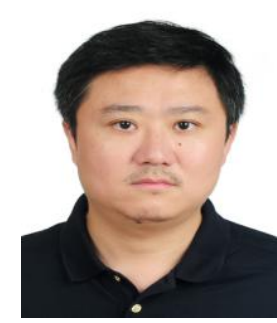

Yi Wang was born in Chongqing, China in 1982. He is currently a $\mathrm{PhD}$ candidate in linguistics from Southwest University, China.

$\mathrm{He}$ is currently a lecturer in the School of Foreign Languages, Chongqing University of Posts and Telecommunications, Chongqing, China. His research interests include cognitive linguistics, construction grammar, the interface between syntax and semantics. 